[Agr. Biol. Chem., Vol. 34, No. 11, p. 1603 1609, 1970]

\title{
An Aspect of Urea Cycle Enzymes in Goat
}

\author{
By Koichi Shimbayashi and Toshio Yonemura \\ National Institute of Animal Health, Kodaira-city, Tokyo, Japan \\ Received January 14, 1970
}

\begin{abstract}
A large amount of ammonia is produced in the rumen and some portion of the ammonia are absorbed into the portal blood through the rumen mucosa. Accordingly, it seems that ammonia detoxication is more necessary for the ruminant than for the nonruminant. Activities of the urea cycle enzymes as principal instrument for ammonia detoxication in goat were investigated in this experiment.

The activities of the urea cycle enzymes of goat were found to be very similar to those of rat reported by other authors. The activities of the urea cycle enzymes were affected by the protein level of diet. Administration of magnesium aspartate increased the activities of argininosuccinate synthetase and arginase, and had some effect on the concentrations of citrulline, aspartic acid, and urea in the liver.
\end{abstract}

It is well known that the protein fed is converted into microbial protein in the rumen. It is also understood that ammonia produced by ruminal microorganisms is absorbed from the rumen into portal blood stream and converted into urea by the liver. Urea has been used as a source of nitrogen in diet. It, however, has been thought that the employment of urea would be dangerous if the feeding conditions were inadequate. In such a case, the breakdown of urea into ammonia in the rumen might occur rapidly, and as a consequence, a large amount of ammonia produced might have to escape through the rumen into portal blood.

If the detoxication of such a large amount of ammonia by the liver via the urea cycle is not sufficient, the level of ammonia in the blood stream will elevate, and the toxic symptoms will develop." ${ }^{1}$ It was observed that cows fed on a high protein diet had often suffered from the disturbance of reproduction. ${ }^{2}$ It is suspected that such disturbance

\footnotetext{
1) D. Lewis, K. J. Hill and E. F. Annison, Biochem. J., 66, 587 (1957).

2) T. Yonemura et al., "Studies on Nutritional Disorder of Milking Cow," Norinsuisan gijutsukaigi, 1964 , p. $139 \sim 379$.
}

of reproduction might be caused by the ammonia intoxication.

The relationship between serum urea level and the amount of protein taken by ruminant has been investigated in our laboratory. ${ }^{31}$ Lewis ${ }^{4)}$ compared the concentration of rumen ammonia with the concentration of urea in the blood, and found a general relationship.

The present study is concerned with the urea synthesis system as a detoxication mechanism of ammonia using goats as ruminant and with some factors affecting the system.

\section{MATERIAL AND METHOD}

Animals. Growing Saanen hybrid with Japanese native strain goats weighing about 10 to $20 \mathrm{~kg}$ were used. They were divided into three groups. The first group was placed on diet $A$ which contained $8.9^{\circ}$ crude protein, the second one on diet $\mathrm{C}$ which contained $20 \%$ crude protein, and the third one on diet A supplemented with $2 \%$ urea. The last diet contained 2.33\% nitrogen and the nitrogen content

3) Y. Ide, K. Shimbayashi and T. Yonemura, Jap. J. Zootech. Sci., 38, 110 (1967).

4) D. Lewis, J. Agric. Sci., 48, 438 (1957). 
TABle I-a. IngREdient Composition of Diets

\begin{tabular}{lcc}
\hline & \multicolumn{2}{c}{ Diet } \\
\cline { 2 - 3 } Composition & A & $\mathrm{C}$ \\
\hline Beet pulp & $58 \mathrm{~kg}$ & $58 \mathrm{~kg}$ \\
Corn & 41 & 4 \\
Soybean meal & - & 37 \\
$\mathrm{CaHPO}_{4} \cdot 2 \mathrm{H}_{2} \mathrm{O}$ & 0.4 & 0.4 \\
$\mathrm{CaCO}$ & 0.1 & 0.1 \\
$\mathrm{NaCl}$ & 0.4 & 0.4 \\
Vitamin A-D & 0.05 & 0.05 \\
\hline
\end{tabular}

a) Contained 10,000 and 3,000 I.U./g of vitamin $A$ and $\mathrm{D}$, respectively.

Table I-b. Chemical Composition of Diets

\begin{tabular}{lcc}
\hline & \multicolumn{2}{c}{ Diet } \\
\cline { 2 - 3 } Composition & $\mathrm{A}$ & $\mathrm{C}$ \\
\hline Moisture & $13.20^{\circ}$ & $12.90^{\circ}$ \\
Crude protein & 8.9 & 20.9 \\
Ether extract & 1.6 & 1.1 \\
Crude fiber & 11.0 & 11.8 \\
N-free extract & 61.5 & 48.2 \\
Crude ash & 3.8 & 5.1 \\
\hline
\end{tabular}

was $0.91 \%$ higher than that of $\operatorname{diet} A$. The details of the two diets used are given in Table $\mathrm{I}-\mathrm{a}$ and I-b. All the animals were fed $95 \mathrm{~g}$ of rations per metabo. lic body size and allowed to drink water ad libitum. The feeding period was for about one month.

Administration of magnesium aspartate. This experiment was done in order to check the influence of magnesium aspartate on the activities of the urea cycle enzymes. Animals fed on the diet $\mathrm{C}$ were used in the administration experiment. They were divided into two groups. One group was used as control and the other group was orally administered magnesium aspartate at 100 to $200 \mathrm{mg}$ per $\mathrm{kg}$ of body weight for about 7 to 14 days.

Analytical methods. Blood samples were collected from the jugular vein before feeding in the morning and at different intervals of time after feeding.

For amino acid analysis, the blood was processed according to the procedure described in the previous paper $^{5}$ and the amino acids in picric acid extracts of plasma were measured by ion-exchange chromatography. ${ }^{6)}$ Free amino acid in the liver was also measured. The liver was homogenized in an equal volume of water by a Waring blender and three volumes of 10 picric acid was added to the homogenate. The mixture was stirred for $15 \mathrm{~min}$ at $40^{\circ} \mathrm{C}$. The amino acids in the picric acid extracts were measured by ion-exchange chromatography in the similar manner to the blood sample. Magnesium in the serum was measured by the procedure of titan yellow. ${ }^{7)}$ Urea in the serum and liver was measured by the procedure of diacetylmonoxim. ${ }^{8}$ Ammonia was measured by the method of Seligson. ${ }^{91}$

Enzyme assay. At the end of feeding period, the animals were slaughtered. The liver was rapidly removed. One gram of liver was homogenized in $9 \mathrm{ml}$ of ice-cold distilled water in a glass Potter-Elvehjem homogenizer for I min. Furthermore, homogenate (1:10) was diluted with ice-cold distilled water in order to make the most convenient preparations for each enzyme assay, and $0.3 \mathrm{ml}$ of the diluted homogenates were used for all enzyme assays. The assays were based on the colorimetric determination of urea and citrulline by the method of Archibald, 10 as modified by Ratner. ${ }^{11}$

The methods were principally the same as those of Brown and Cohen ${ }^{12}$ for the assay of the urea cycle enzymes in tadpole liver.

Carbamyl phosphate synthetase. The assay medium contained $50 \mu$ moles of ammonium bicarbonate, 5 $\mu$ moles of ATP, $5 \mu$ moles of L-ornithine, $5 \mu$ moles of N-acetyl-L-glutamate, $10 \mu$ moles of $\mathrm{MgSO}_{4} \cdot 7 \mathrm{H}_{2} \mathrm{O}, 10$ $\mu$ moles of phosphoenolpyruvate, $25 \mu \mathrm{g}$ of pyruvate

5) K. Shimbayashi and T. Yonemura, Nat. Inst. Anim. Helth Quart., 3, 36 (1963).

6) S. Moore, D. H. Spackman and W. H. Stein, Analyt. Chem., 30, 1185 (1958).

7) H. O. Kunkel, P. B. Pearson and B. S. Schweigert, J. Lab. Clin. Med., 23, 1079 (1938).

8) A. A. Ormsby, J. Biol. Chem., 146, 595 (1942).

9) D. Seligson and H. Seligson, J. Lab. Clin. Med., 38, 324 (1951).

10) R. M. Archibald, J. Biol. Chem., 156, 121 (1944). 11) "Methods in Enzymology," Vol. II, ed. by $S$. P. Colowick and N. O. Kaplan, Academic Press Inc., New York, N. Y., 1955, p. 357.

12) G. W. Brown and P. P. Cohen, J. Biol. Chem., 243, 1769 (1959). 
kinase, 150 to 200 units of ornithine transcarbamylase, and 1:40 homogenate in a final volume of 1 $\mathrm{ml}$. The solution was saturated with $\mathrm{CO}_{2}$ to make pH 6.8 immediately before use. The incubation time was for $15 \mathrm{~min}$

Ornithine transcarbamylase. The medium contained $20 \mu$ moles of L-ornithine, $90 \mu$ moles of sodium glycylglycine, $20 \mu$ moles of dilithium carbamyl phosphate, and 1:400 homogenate in a final volume of $2 \mathrm{ml}$. Carbamyl phosphate was added just before use because of its instability in solution. The incubation time was for $15 \mathrm{~min}$.

Arginine synthetase (over-all system of Ratner et al. ${ }^{11 \prime}$ ) The assay medium contained $5 \mu$ moles of $\mathrm{MgSO}_{4}$. $7 \mathrm{H}_{2} \mathrm{O}, 5 \mu$ moles of ATP, $5 \mu$ moles of L-citrulline, 5 umoles of L-aspartate, $50 \%$ moles of potassium phosphate buffer at $\mathrm{pH} 7.0,10 \mu$ moles of phosphoenolpyruvic acid, $25 \mu \mathrm{g}$ of pyruvate kinase, 25 units of arginase, and $1: 20$ homogenate in a final volume of $1 \mathrm{ml}$ The incubation time was for $60 \mathrm{~min}$.

Arginiosuccinate cleavage enzyme. The assay medium contained $3 \mu$ moles of argininosuccinic acid, $50 \mu$ moles of $\mathrm{MnSO}_{4} \cdot \mathrm{H}_{2} \mathrm{O}, 50 \mu$ moles of potassium phosphate buffer at $\mathrm{pH} 7.5,50$ units of arginase, and 1:40 homogenate in a final volume of $1 \mathrm{ml}$. The incubation time was for $30 \mathrm{~min}$.

Arginase. The assay medium contained $25 \mu$ moles of L-arginine, $0.5 \mu$ moles of $\mathrm{MnSO}_{4} \cdot \mathrm{H}_{2} \mathrm{O}, 50 \mu$ moles of sodium glycinate buffer at $\mathrm{pH} 9.5$, and $1: 1000$ homogenate in a final volume of $2 \mathrm{ml}$. The incubation time was for $30 \mathrm{~min}$.

Argininosuccinic acid was synthesized from fumarate and arginine by the method of Ratner et al. ${ }^{131}$ using the splitting enzyme which had been prepared from beef liver as reported by the same authors. ${ }^{141}$ Ornithine transcarbamylase and arginase having approximately 350 and 1500 units per $\mathrm{mg}$ of protein, respectively, were prepared from beef liver by the method of Burnett and Cohen, ${ }^{15}$ and Bach and Killip, ${ }^{16)}$ respectively.

All enzyme assays were performed at $37^{\circ} \mathrm{C}$, and the reactions were stopped by the addition of $5 \mathrm{ml}$ of $0.5 \mathrm{~N}$ perchloric acid. The protein precipitates were removed by centrifugation, and aliquots of the

Table 11. Effect of Protein Level in Diet on Hepatic Activities of URea Ciycle Enzymes

\begin{tabular}{|c|c|c|c|c|c|c|c|c|}
\hline $\begin{array}{c}\text { Goat } \\
\text { no. }\end{array}$ & Diet & $\begin{array}{l}\text { Serum } \\
\text { urea-N } \\
\mathrm{mg} / \mathrm{dl}\end{array}$ & $\begin{array}{l}\text { Liver } \\
\mathrm{NH}_{3-\mathrm{N}} \\
\mathrm{mg} / 100 \mathrm{~g} \text { wet }\end{array}$ & $\begin{array}{l}\text { Carbamyl } \\
\text { phosphate } \\
\text { synthetase } \\
\text { units } / g^{a t}\end{array}$ & $\begin{array}{l}\text { Ornithine } \\
\text { transcar- } \\
\text { bamylase } \\
\text { units/g }\end{array}$ & $\begin{array}{l}\text { Arginine } \\
\text { synthetase } \\
\text { units } / \mathrm{g}^{a}\end{array}$ & $\begin{array}{l}\text { Arginino-suc- } \\
\text { cinate cleavage } \\
\text { enzyme } \\
\text { units } / \mathrm{g}^{a}\end{array}$ & $\begin{array}{l}\text { Arginase } \\
\text { units/ga) }\end{array}$ \\
\hline 3 & $\mathrm{~A}$ & 6.0 & 21.5 & 301 & 14,270 & 63 & 92 & 8,668 \\
\hline 7 & A & 5.0 & 16.3 & 267 & 11,570 & 48 & 115 & 9,000 \\
\hline 8 & A & 5.5 & 29.3 & 174 & 9,730 & 40 & 92 & 5,050 \\
\hline \multicolumn{2}{|c|}{ Average } & 5.5 & 22.3 & 247 & 11,860 & 50 & 100 & 7,573 \\
\hline \multirow{4}{*}{\multicolumn{2}{|c|}{$\begin{array}{l}13 \text { A }+2 \% \text { urea } \\
14 \text { A+2\% urea } \\
15 \text { A }+2 \% \text { urea } \\
\text { Average }\end{array}$}} & a 8.0 & & 192 & 15,880 & 65 & 224 & 8,160 \\
\hline & & 8.5 & & 339 & 18,400 & 110 & 143 & 7,840 \\
\hline & & a 8.0 & & 376 & 16,930 & 122 & 133 & 9,410 \\
\hline & & 8.2 & & 302 & 17,070 & 99 & 166 & 8,410 \\
\hline 2 & $\mathrm{C}$ & 37.5 & 13.8 & 328 & 19,780 & 111 & 185 & 6,733 \\
\hline 9 & C & 26.3 & 14.0 & 238 & 13,000 & 112 & 195 & 8,833 \\
\hline 10 & $\mathrm{C}$ & 43.0 & 11.5 & 283 & 14,500 & 114 & 209 & 14,311 \\
\hline \multicolumn{2}{|c|}{ Average } & 35.6 & 13.1 & 283 & 15,760 & 112 & 196 & 9,959 \\
\hline
\end{tabular}

a) One unit is defined as one $\mu$ mole of product per hour.

13) S. Ratner, B. Petrack, and O. Pochovansky, ibid., 204, 95 (1953).

14) S. Ratner, W. P. Anslow, Jr., and B. Petrack, J. Biol. Chem., 204, 115 (1953).
15) G. H. Burnett and P. P. Cohen, J. Biol. Chem., (1957).

16) S. Bach and J. D. Killip, Biochim. Biophys. Acta. 229, 33729,273 (1958), 
supernatant were used for development of color. Blanks included a substrate blank, in which the assay medium minus homogenate was incubated, and a time blank, in which the perchloric acid was added to the incubation mixture plus homogenate at zero time. As the standard the incubation media were used to which urea or citrulline had been added. One unit of the enzyme was defined as the amount of enzyme producing $1 \mu$ mole of product per hour under the assay conditions, and the enzyme activity was expressed as units per gram (wet weight) of the liver.

\section{RESULTS}

Relationship between activities of urea cycle enzymes and dietary protein level

The animals were healthy regardless of the diets and consumed rations almost completely. The effects of varying the protein level of the diet on hepatic levels are shown in Table II. The hepatic activities of urea cycle enzymes were different between the $8.90^{\circ}$ protein diet and the $20 \%$ protein diet. Animals on the higher protein diet had generally higher activity of each urea cycle enzyme; the activity increased significantly in arginine synthetase and argininosuccinate cleavage enzyme, whereas the increase in activities of other enzymes were relatively slight. The serum level of urea nitrogen varied from 5.5 $\mathrm{mg} / \mathrm{dl}$ on $8.90 \%$ protein diet to $35.6 \mathrm{mg} / \mathrm{dl}$ on
$20.9 \%$ protein diet. The hepatic level of ammonia nitrogen was conversely higher in the animals on the lower protein diet than in those on the higher protein diet. The activities of urea cycle enzymes were higher in the animals on the lower protein diet supplemented with urea at $2 \%$ level than in those on the lower protein diet alone.

\section{Effect of magnesium aspartate on urea cycle enzymes}

Table III summarizes the results of investigation about the effect of magnesium aspartate on the urea cycle enzymes in the liver. All the animals used for the investigation were

Table III. EFFect of Mg-Aspartate on Activities of Hepatic Urea Cycle Enzymes

\begin{tabular}{lcc} 
Enzyme & \multicolumn{2}{c}{ Goat $^{a}$} \\
\cline { 2 - 3 } & Control & $\begin{array}{c}\text { Mg-Aspartate } \\
\text { administration }\end{array}$ \\
\hline Units/g & units/g \\
$\begin{array}{c}\text { Carbamylphosphate } \\
\text { synthetase }\end{array}$ & $255 \pm 45^{b}$, & $255 \pm 75$ \\
$\begin{array}{c}\text { Ornithin trans- } \\
\text { carbamylase }\end{array}$ & $16,800 \pm 3,800$ & $14,200 \pm 2,500$ \\
$\begin{array}{c}\text { Arginine synthetase } \\
\text { Argininosuccinate } \\
\text { cleavage enzyme }\end{array}$ & $98 \pm 19$ & $120 \pm 12$ \\
Arginase & $8,300 \pm 3,200$ & $12,083 \pm 1,200$
\end{tabular}

a) Three animals were used in each group, and fed on the diet $\mathrm{C}$.

b) Mean \pm SD.

Table IV. Comparison of Differences in Serum Level of Urea and Magnesium BETWEEN BEFORE AND AFTER FEEDING

\begin{tabular}{|c|c|c|c|c|c|c|c|}
\hline \multirow{2}{*}{ Group } & \multirow{2}{*}{$\begin{array}{l}\text { Animal } \\
\text { no. }\end{array}$} & \multicolumn{3}{|c|}{ Serum urea } & \multicolumn{3}{|c|}{ Serum magnesium } \\
\hline & & $\begin{array}{l}\text { Before } \\
\mathrm{mgN} / \mathrm{dl}\end{array}$ & $\begin{array}{c}\text { After } 6 \mathrm{hr} \\
\mathrm{mgN} / \mathrm{dl}\end{array}$ & $\begin{array}{c}\text { Difference } \\
\mathrm{mgN} / \mathrm{dl}\end{array}$ & $\begin{array}{l}\text { Before } \\
\mathrm{mg} / \mathrm{dl}\end{array}$ & $\begin{array}{l}\text { After } 6 \mathrm{hr} \\
\mathrm{mg} / \mathrm{dl}\end{array}$ & $\begin{array}{c}\text { Difference } \\
\mathrm{mg} / \mathrm{dl}\end{array}$ \\
\hline \multirow{3}{*}{ Control } & 12 & 36.5 & 27.0 & -9.5 & 2.7 & 3.0 & 0.3 \\
\hline & 21 & 39.0 & 27.0 & -12.0 & 2.8 & 3.2 & 0.4 \\
\hline & 24 & 47.5 & 38.5 & -9.0 & 2.8 & 3.2 & 0.4 \\
\hline \multirow{3}{*}{ Mg-Aspartate administration } & 19 & 32.0 & 26.2 & -5.8 & 2.8 & 3.6 & 0.8 \\
\hline & 20 & 35.5 & 31.0 & -4.5 & 2.4 & 3.1 & 0.7 \\
\hline & 23 & 51.5 & 46.0 & -5.5 & 2.4 & 3.3 & 0.9 \\
\hline
\end{tabular}


fed on the diet $\mathrm{C}$, high protein diet. The activities of arginine synthetase and arginase increased significantly. Twenty-four $\%$ increase in arginine synthetase and $46, \%$ increase in arginase were the most remarkable, whereas there were no significant changes in other enzymes.

The difference in serum levels of urea and magnesium between at the time just before feeding and at $6 \mathrm{hr}$ after feeding were compared with both groups. Table IV shows the differences of these values. Decreases in urea level of the serum in the groups of diet $\mathrm{C}$ and diet $C$ supplemented with magnesium aspartate were 10.2 and $5.3 \mathrm{mgN} / \mathrm{dl}$ on the average, respectively. Therefore, it is assumed that urea formation in the animals on the diet supplemented with magnesium aspartate might be accelerated. Increases in the serum level of magnesium were larger in the animals on the supplemented diet than in those on the non-supplemented diet. This fact may show that added magnesium as aspartate to the diet was actively absorbed from the digestive tract.

Free amino acids of plasma and liver

The concentrations of some free amino acids
TABle VI. Free AMino Acios in LIVER of GoAT FED ON C DIET AND G DIET ADDED Mg-Aspartate

\begin{tabular}{lccc} 
& \multicolumn{2}{c}{ C diet } & C diet + Mg-aspartate \\
\cline { 2 - 4 } & No. 21 & No. 19 & No. 20 \\
& mg/100 liver wet weight \\
Taurine & 67.8 & 34.2 & 23.0 \\
Aspartic acid & 33.9 & 27.8 & 26.9 \\
Threonine & 5.79 & 7.00 & 5.33 \\
Serine & 25.0 & 13.1 & 20.8 \\
Gluiamic acid & 190.3 & 122.2 & 121.4 \\
Citrulline & 12.1 & 3.68 & 1.93 \\
Glycine & 89.3 & 49.3 & 54.3 \\
Alanine & 27.6 & 23.0 & 26.4 \\
Cystine & 15.5 & 5.45 & 11.8 \\
Valine & 13.0 & 11.5 & 11.6 \\
Methionine & 4.33 & 3.58 & 1.19 \\
Isoleucine & 7.35 & 7.35 & 6.17 \\
Leucine & 17.2 & 11.0 & 8.66 \\
Tyrosine & 7.79 & 5.80 & 5.40 \\
Phenylalanine & 8.09 & 5.95 & 7.04 \\
Lysine+Ornithine & & & \\
Histidine & 32.3 & 43.4 & 48.7 \\
Arginine & 10.2 & 14.9 & 18.5 \\
& trace & trace & 2.44
\end{tabular}

a) The values were calculated as lysine.

b) These values could not be measured by the chromatography because of very small amounts.

Table V. Some Plasma free Amino Acids of Goats fed on a and C Diet

\begin{tabular}{lcccc} 
& \multicolumn{2}{c}{ C diet } & & A diet \\
\cline { 2 - 3 } & $\begin{array}{c}\text { Before feeding } \\
\mathrm{mg} / \mathrm{dl}\end{array}$ & $\begin{array}{c}3 \mathrm{hr} \text { after fceding } \\
\mathrm{mg} / \mathrm{dl}\end{array}$ & $\begin{array}{c}6 \mathrm{hr} \text { after feeding } \\
\mathrm{mg} / \mathrm{dl}\end{array}$ & $\begin{array}{c}\text { Before feeding } \\
\mathrm{mg} / \mathrm{dl}\end{array}$ \\
\hline Taurine & 0.96 & 1.17 & 1.27 & 1.73 \\
Aspartic acid & 0.33 & 0.34 & 0.35 & 0.26 \\
Threonine & 1.09 & 0.76 & 1.20 & 0.52 \\
Serine & 1.84 & 1.97 & 1.80 & 1.64 \\
Glutamic acid & 0.98 & 0.83 & 0.81 & 1.17 \\
Glycine & 5.96 & 5.94 & 6.33 & 0.97 \\
Alanine & 1.29 & 1.16 & 1.43 & 0.56 \\
Cystine & 0.55 & 0.91 & 0.96 & 2.80 \\
Valine & 4.50 & 2.18 & 2.76 & 1.04 \\
Citrulline & 3.45 & 2.43 & 1.75 & 8.8 \\
Urea-N & 35.7 & 36.8 & 29.8 & \\
\hline
\end{tabular}

These values are expressed as average of 3 animals for each group. 
in the plasma and the liver were determined. The concentration of most amino acids in the plasma were similar to those in cow. ${ }^{17}$ Generally, the concentration of glycine had been found to be of significantly high level in ruminant, and the fact was also observed in this experiment using goat. The goats fed on the diet containing low protein showed the higher concentration of plasma glycine than the animals fed on the diet containing high protein, whereas the plasma concentration of citrulline was higher in goats fed on high protein diet than in goats fed on low protein diet (Table V).

It was observed that the concentrations of most free amino acids were higher in the liver than those in the plasma. The hepatic concentrations of glutamic acid and aspartic acid were remarkably high, although the plasma concentration were relatively low. Moreover, the concentrations of arginine and citrulline were low in the liver, especially in arginine, although these amino acids were found in appreciable amount in the plasma. ${ }^{5}$ As shown in the Table VI, the concentration of aspartic acid in the liver was slightly smaller in the animals given the diet with magnesium aspartate than in the animals given the diet without this compound. Furthermore, the hepatic concentration of citrulline was higher in the animals given the diet without magnesium aspartate than in the animals given the diet with this compound.

\section{DISCUSSION}

There have been numerous studies on the activities of amino acid catabolism in the liver of rats in relation to their dietary conditions. Schimke ${ }^{18}$ determined the activities of the urea cycle enzymes of rats fed diets containing varying amounts of protein, and

17) K. Shimbayashi, Y. Ide and T. Yonemura, Agr. Biol. Chem., 31, 628 (1967).

18) R. T. Schimke, J. Biol. Chem., 237, 459 (1962). demonstrated that the activities were directly proportional to the amount of daily consumption of protein. On the other hand, Brown et al. ${ }^{12)}$ had shown the comparable increases in all urea cycle enzymes of tadpole undergoing metamorphosis. The phenomena which had been observed by Schimke was also found in goat used in this experiment. Namely, under the conditions of feeding which induced a several-fold increase in the serum level of urea nitrogen, the activities of most enzymes of urea synthesis increased. Especially, the activities of arginine synthetase and argininosuccinate cleavage enzyme increased to larger extent than those of other enzymes. It is thought that increasing the activity of arginine synthetase, which is present in least abundance is most economical to the animal.

A slight increase in the serum level of urea nitrogen by feeding on diet $A$ supplemented with urea in $2 \%$ was observed, although the activities of urea cycle enzymes increased significantly. Therefore, it is assumed that urea cycle enzymes are accelerated by ammonia in the liver.

The effect of magnesium aspartate added to the diet on the urea synthesis system was examined. Of the urea cycle enzymes the activity of arginine synthetase, present in least abundance, increased about 20\%. This finding resembled the result of a similar unpublished experiment using rats. As mentioned above, the fact seems to be economical to the animal.

The concentration of aspartic acid and citrulline in the liver was lower in the animals supplied with magnesium aspartate than in the animal without the supply. From the result, it is assumed that magnesium aspartate stimulated urea synthesis by increasing the activity of arginine synthetase.

It was obtained from another unpublished experiment that the amount of urea excreted into the urine was about 400 mmoles per day using a goat weighing $12 \mathrm{~kg}$ fed on the high protein diet. Amount of urea produced via 
the urea cycle is thought to be very close on molar basis to that of aspartic acid associated with the arginine synthetase, if arginine from any sources other than the urea cycle is present only in small amount. Based on such an assumption, about 400 mmoles of aspartic acid may be required for the synthesis of 400 mmoles of urea day a goat. Although some part of urea produced in the liver directly come from arginine of other sources, it is thought that urea synthesis may need a large amount of aspartate in the liver. Schimke ${ }^{18 !}$ reported that glutamic-oxaloacetic acid transaminase in rat liver increased by feeding on the higher protein diet whereas glutamic dehydrogenase decreased. Katunuma and $\mathrm{Okada}^{191}$ stated interconversion of gluta-

19) N. Katunuma and M. Okada, J. Vitaminology, 8, 309 (1962). mate and aspartate by the coupling reactions between glutamic-oxaloacetic acid transaminase in mitochondria and the tricarboxylic acid cycle. It is also thought by these investigators that aspartate is actively formed in the liver.

On the other hand, fumaric acid which is formed from the reaction of aspartate with citrulline by arginine synthetase may be converted to oxaloacetic acid via the tricarboxylic acid cycle. The resultant oxaloacetic acid may be used for reformation of aspartate by transaminase. Therefore, it is assumed that the consumption of oxaloacetic acid may be larger in the ruminant compared with the monogastric animal and it may easily lead to keton body formation having relation to ketosis. 